\title{
Cost analysis of hemophilia treatment in a Brazilian public blood center
}

\section{Custo-análise do tratamento da hemofilia em um hemocentro público brasileiro}

\author{
Adriana Aparecida Ferreira ${ }^{1,2}$ (D), Igor Vilela Brum³ (D), João Vítor de Lanna Souza3 (D), \\ Isabel Cristina Gonçalves Leite 4 (D) \\ 'Serviço de Hematologia, Hospital Universitário, Universidade Federal de Juiz de Fora (UFJF) - Juiz de Fora (MG), Brasil. \\ ${ }^{2}$ Hemocentro Regional de Juiz de Fora, Centro de Hematologia e Hemoterapia de Minas Gerais, Fundação HEMOMINAS - Juiz de \\ Fora (MG), Brasil. \\ ${ }^{3}$ Faculdade de Medicina, Universidade Federal de Juiz de Fora (UFJF) - Juiz de Fora (MG), Brasil. \\ ${ }^{4}$ Programa de Pós-graduação em Saúde e em Saúde Coletiva, Universidade Federal de Juiz de Fora (UFJF) - Juiz de Fora (MG), \\ Brasil.
}

How to cite: Ferreira AA, Brum IV, Souza JVL, Leite ICG. Cost analysis of hemophilia treatment in a Brazilian public blood center. Cad Saúde Colet, 2020;28(4):556-566. https://doi.org/10.1590/1414-462X202028040484

\begin{abstract}
Background: hemophilia is a rare coagulopathy, treated by replacing the missing blood clotting factor. Objective: to assess the direct costs of hemophilia treatment from the perspective of the Unified Health System, highlighting the impact costs of new therapeutic modalities. Method: partial economic assessment of the direct costs of hemophilia, in which were collected data from patient records from 2011 to 2015, at the Blood Center in the city of Juiz de Fora. Costs were assigned to consultations, exams, hospitalizations, and medications according to the price list of the National Health Surveillance Agency (in Portuguese ANVISA) and the Table of Procedures, and Medications. Results: among 98 patients evaluated, 76 had hemophilia A, and $43.3 \%$ presented severe hemophilia. The number of consultations and the consumption of Clotting Factor Concentrates (CFCs) were higher in severe hemophilia. Hospitalizations were rare. Direct costs increased 286.8\% from 2011 to 2015. The mean annual cost per patient was $\mathrm{R} \$ 57,416.43$, with no significant difference between hemophilia $A$ and $B$. The expenditures for factor concentrates amounted to $99.46 \%$ of total costs. The actual impact cost was more than $\mathrm{R} \$ 6,000,000.00$. Conclusion: the direct costs of hemophilia were high, mainly due to factor concentrates. There was an increase in costs with the incorporation of technologies, although there are some areas with potential inefficiencies.
\end{abstract}

Keywords: hemophilia A; hemophilia B; costs and cost analysis; joint diseases.

\section{Resumo}

Introdução: hemofilia é uma coagulopatia rara, tratada com reposição do fator de coagulação deficiente. Objetivo: avaliar custos diretos do tratamento da hemofilia pela perspectiva do Sistema Único de Saúde brasileiro, destacando o impacto nos custos das novas modalidades terapêuticas. Método: análise econômica parcial dos custos diretos da hemofilia. Foram coletados dados de prontuários de pacientes do Hemocentro de Juiz de Fora de 2011-2015. Aos atendimentos, exames, hospitalizações e medicamentos, foram atribuídos custos conforme as Tabelas de Preços da Agência de Vigilância Sanitária e de Procedimentos e Medicamentos do SUS. Resultados: entre 98 pacientes avaliados, 76 tinham hemofilia A e 43,3\%, hemofilia grave. O número de consultas e o consumo de concentrados de fatores da coagulação foram mais altos na hemofilia grave. Hospitalizações foram raras. Os custos diretos aumentaram $286,8 \%$ entre 2011-2015. O custo anual médio por paciente foi $\mathrm{R} \$ 57.416,43$ sem diferença significativa entre

Study carried out at Hemocentro Regional de Juiz de Fora - Juiz de Fora (MG), Brasil.

Correspondence: Adriana Aparecida Ferreira. E-mail: adriana.hemato@gmail.com

Financial support: none.

Conflict of interests: nothing to declare.

Received on: Oct. 09, 2018. Accepted on: Oct. 20, 2019 
hemofilia A e B. Os concentrados de fator corresponderam a $99,46 \%$ dos custos totais. O impacto nos custos foi de mais de $\mathrm{R} \$ 6.000 .000,00$. Conclusão: custos diretos da hemofilia são altos, principalmente devido aos concentrados de fator. O aumento nos custos com as novas tecnologias foi muito elevado embora ainda haja áreas com ineficiências no tratamento da hemofilia.

Palavras-chave: hemofilia A; hemofilia B; custos e análise de custos; artropatias.

\section{INTRODUCTION}

Congenital hemophilia is a Rare Bleeding Disorder (RBD) (incidence: 1 in 10,000-30,000 male births), affecting male individuals, almost exclusively, whose pathophysiology is related to the deficiency or abnormality of blood coagulation factor VIII activity (in hemophilia A) or factor IX activity (in hemophilia B). The clinical characteristic of hemophilia is the tendency to bleed, whose severity is related to the residual plasma level of the deficient factor. In its severe forms, bleeding may be spontaneous, affecting any organ or tissue, but especially the joints ${ }^{1}$. Recurrent hemarthroses, typical of the disease, result in a vicious cycle that culminates in chronic synovitis and progressive irreversible cartilage degeneration, characterizing hemophilic arthropathy, which is the most frequent and often incapacitating complication in patients with hemophilia ${ }^{2}$. Muscular atrophy, joint deformities, and mobility problems usually appear as early as the first two decades of life ${ }^{1,2}$.

The treatment of hemophilia is based on replacement of the deficient clotting factor, which can be done in order to control bleeding (episodic treatment) or to prevent it (prophylaxis) ${ }^{3}$. Prophylaxis, when initiated early, is potentially capable of preventing arthropathy, deficiencies, and disabilities, and is considered the "gold standard treatment" for children with severe hemophilia'. However, when arthropathy already exists, prophylaxis cannot reverse it, but it seems to decrease its progression and reduce pain, inflammation, and number of bleeding episodes, being able to maintain patient mobility, reduce absenteeism at school or at work, and improve quality of life ${ }^{4,5}$.

In the past few years, significant therapeutic advances have been achieved with very high investments, such that hemophilia remains one of the most costly and challenging diseases with regard to proper management ${ }^{6-8}$. A recent American study showed that the mean annual direct cost for the treatment of an individual with hemophilia exceeds $\$ 150,000$, of which 86$92 \%$ are costs for Clotting Factor Concentrates (CFCs). Direct costs are higher for prophylaxis or if the patient has arthropathy, Acquired ImmunoDeficiency Syndrome (AIDS) or Hepatitis C Virus (HCV) infection, or develops coagulation factor inhibitors ${ }^{9}$.

The high costs associated with treatment impose a significant financial "burden", not only on the individual, but on the entire health system and on society ${ }^{10}$, making hemophilia a constant target for attempts by healthcare provider services to cut costs ${ }^{11}$. In Brazil, the entire provision of CFCs is financed by the Unified Health System (in Portuguese Sistema Único de Saúde (SUS)). The multidisciplinary treatment of patients with hemophilia is conducted in blood centers, also belonging to the public health network, distributed throughout the country ${ }^{2}$.

Despite having been used for several decades in developed countries, prophylaxis was only incorporated by the SUS in November of $2011^{2,12,13}$. The inclusion of recombinant factor VIII and Immune Tolerance Induction (ITI), also known as Immune Tolerance Therapy (ITT), for patients with inhibitors is somewhat more recent ${ }^{14}$. After a complete review of the literature, it is believed that no cost analysis study has been conducted in Brazil since the introduction of these new types of treatment. The objective of this study was to evaluate the evolution of the direct medical costs of the treatment of individuals with hemophilia according to the SUS perspective, between 2011 and 2015, highlighting the real impact costs in a blood center of Southeastern Brazil.

\section{METHOD}

\section{Type of study}

This study was related to a cost of illness type of partial economic evaluation, focused on the direct medical costs of hemophilia treatment, which were identified and assessed, according to the SUS perspective, in a micro-costing approach, based on empirical data. 


\section{Ethical aspects}

The study was previously approved by the Research Ethics Committee of the Hematology Center Foundation and Hemotherapy Minas Gerais- (HEMOMINAS), registered under number 1.276.213.

\section{Study population and location}

The research was conducted at the Regional Blood Center of Juiz de Fora (RBCJF) (in Portuguese Hemocentro Regional de Juiz de Fora (HRJF)), in Southeastern Brazil, administered by the Minas Gerais State Government, following guidelines of the Blood and Hemoderivatives General Administration. The HRJF is responsible for the care of patients with hereditary coagulopathies in the regions of Zona da Mata and Campo das Vertentes situated in the state of Minas Gerais, whose population is estimated of more than 2.5 million. Due to geographic proximity, some patients, from the regions of Serrana and Três Rios in the state of Rio de Janeiro State, are also treated at the HRJF.

The HRJF provides patients with multidisciplinary teams (from Hematology, Nursing, Psychology, Dentistry, and Social Assistance). Infusions of CFCs are routinely administered by nurse technicians at the blood center, after a medical evaluation of patients. Patients are trained by nurses to perform home infusions of factor concentrates. This training takes place at the blood center during infusions prescribed to treat the bleeding events. There is no referral hospital in the region for the hospitalization of patients with hemophilia, but in urgent/ emergency cases, patients are advised to seek medical care at the Juiz de Fora Emergency Care Hospital, which employs hematology specialists to be on call.

In the second half of 2016, medical records and records on the dispensing of CFCs and hemostatic drugs were reviewed for all individuals with hemophilia treated at the HRJF between the following data: 01/01/2011 and 12/31/2015 $(n=98)$. Nine registered patients with hemophilia, who did not present any records of care during this period and those who received only walk-in care, were excluded. Patients were evaluated regarding age, type and severity of hemophilia, and presence of inhibitors. Patients with arthropathy, and serum positive for Human Immunodeficiency Virus (HIV) or HCV were also identified.

\section{Identification of components and allocation of financial costs}

The components included in the direct medical costs of hemophilia treatment were: consumption of CFCs and hemostatic drugs (tranexamic acid and desmopressin); administration of CFCs by nursing technicians; medical consultations with hematologists or orthopedists; urgent medical visits; non-physician professional care (Nursing, Psychology, Dentistry, Social Assistance); ambulatory surgical procedures; hospitalizations (only the main procedure costs); and transfusions of blood components ${ }^{11}$.

Computations included all laboratory exams requested in HRJF consultations, such as hemogram, coagulation tests, coagulation factor inhibitor screening, Liver Function Tests (LFTs), and serologies (HIV, hepatitis B and C, Human T-Lymphotropic Virus (HTLV), syphilis, and Chagas disease). In addition, it was included the image analysis of $x$-rays, ultrasound (US), computed tomography, and Magnetic Resonance Imaging (MRI).

To allocate financial costs to the consultations and procedures, the Table of Procedures, Medications, and Orthoses, Prostheses, and Materials Management System of the SUS (in Portuguese Sistema de Gerenciamento da Tabela Unificada de Procedimentos e OPM do SUS (SIGTAP)) was used. Regarding hospitalizations, due to the difficulty in accessing the hospitals records, only the values corresponding to the main procedure were computed, according to the current table from SIGTAP ${ }^{15}$.

In order to allocate financial costs to CFCs and hemostatic drugs, the values for the maximum selling price to the government were consulted in the price list of the National Health Surveillance Agency (in Portuguese Agência Nacional de Vigilância Sanitária (ANVISA)), without including the Tax on the Circulation of Goods and Services. Since prices are readjusted 
annually, it could be considered the final lists published for each year, such as: December/2011, December/2012, November/2013, December/2014, and December/2015 ${ }^{16}$.

Neither the costs related to physical therapy nor to antiviral treatment for AIDS or hepatitis $C$ were included in this study, since they were carried out in various health services and were not detailed in the HRJF records.

To calculate the mean annual costs per patient, the costs related to physician and nonphysician care, complementary exams, surgeries, transfusions, hospitalizations, and use of CFCs and hemostatic drugs were summarized in each of the years that were included in the study and divided by the number of hemophilia patients treated at the HRJF over that year. Inflation adjustments were not used since these are not routinely used in cost analyses with a short time frame ${ }^{17}$.

\section{Statistical analysis}

The data were collected, reviewed, and analyzed by the researchers. Statistical analyses were performed using the Statistical Package for the Social Sciences (SPSS) v.20. Differences in means were tested using the Mann-Whitney test or the Kruskal-Wallis test, when necessary. These non-parametric tests were used since the data did not present a normal distribution via the Shapiro-Wilk test. The Wilcoxon and Friedman tests were used to compare the mean costs for the same individuals at different moments in the study.

\section{RESULTS}

A total of 98 patients (76 with hemophilia A and 22 with hemophilia B), all males, who were attended during the period covered by the study, were evaluated. In the first year of follow-up, the mean age of individuals with hemophilia $A$ was significantly higher than those with hemophilia B (29.5 versus 15.3 years, $p<0.01)$. The mean age was also higher among patients who were positive for any of the tested serologies ( 40.9 years) than in the group with all negative results ( 17.7 years, $p<0.01)$, and this data may show the contamination of blood components and hemoderivatives that occurred in the 1980s'. Other demographic and clinical aspects are presented in Table 1.

All the patients with AIDS were under regular antiretroviral therapy. No patient with positive serology for hepatitis $C$ received specific treatment during the study period. On average, each patient attended a visit with the hematologist $11.4(0-95)$ per year and $10.9(0-98)$ received infusions of CFCs at the blood center. There was a reduction of $21 \%$ in the number of consultations and 37.3\% in infusions between 2011 and 2015. There were records of only 10 consultations with orthopedists in the period. Urgent and emergency services had a median of zero in all observed years. The multidisciplinary care of patients with hemophilia at the HRJF are described in Table 2.

The need for LFTs was very low (from two to four patients evaluated per year), considering the high percentage of patients with positive serology for HCV. All the medical imaging exams were requested in cases of trauma, or acute or chronic pain. No exam was requested to assist in the early stage of arthropathy, as recommended, and there was no screening for osteopenia or osteoporosis ${ }^{18-20}$.

Regarding medical records of ten patients, it could be found reports of occasional physical therapy follow-up as well as other health services. No surgeries or orthopedic procedures related to hemophiliac arthropathy were performed between 2011 and 2015. One patient with a positive inhibitor test and high inhibitor titer received ITI for nine months, with full response to treatment.

The study also included transfusions of blood components ( 15 red cell concentrates in total); 15 clinical admissions (liver cirrhosis, AIDS complications, muscular hematoma, cervical hematoma with airway obstruction, spinal cord compression, epistaxis/hematemesis, septic arthritis, and hemarthrosis complications); 17 surgical hospitalizations (fracture, multiple trauma, cholecystectomy, testicular torsion, inguinal hernia repair, postectomy, brain tumor resection, and catheter ablation); and 11 surgical procedures performed at the outpatient level 
Table 1. Demographic and clinical aspects of patients with hemophilia at the Regional Blood Center of Juiz de Fora, in the state of Minas Gerais, Brazil, 2011-2015

\begin{tabular}{|c|c|c|c|c|c|}
\hline & 2011 & 2012 & 2013 & 2014 & 2015 \\
\hline Patients & 85 & 90 & 91 & 92 & 94 \\
\hline \multicolumn{6}{|c|}{ Type and severity of hemophilia } \\
\hline Hemophilia A (\%) & $65(76.5)$ & $69(76.7)$ & $71(78)$ & $72(78.3)$ & $73(77.7)$ \\
\hline Severe & 31 & 33 & 32 & 32 & 32 \\
\hline Moderate & 20 & 21 & 21 & 22 & 22 \\
\hline Mild & 14 & 15 & 18 & 18 & 19 \\
\hline Hemophilia B (\%) & $20(23.5)$ & $21(23.3)$ & $20(22)$ & $20(21.7)$ & $21(22.3)$ \\
\hline Severe & 9 & 9 & 9 & 9 & 9 \\
\hline Moderate & 7 & 8 & 8 & 8 & 9 \\
\hline Mild & 4 & 4 & 3 & 3 & 3 \\
\hline \multicolumn{6}{|c|}{ Mean age in years (range) } \\
\hline \multirow{2}{*}{ Total } & 26.1 & 26.2 & 27.2 & 27.8 & 29 \\
\hline & $(2.9-79.8)$ & $(0.7-80.8)$ & $(1.7-81.8)$ & $(2.7-82.8)$ & $(3.7-83.8)$ \\
\hline \multirow{2}{*}{ Hemophilia A } & 29.5 & 29.4 & 30.2 & 30.9 & 32.1 \\
\hline & $(2.9-79.8)$ & $(0.7-80.8)$ & $(1.7-81.8)$ & $(2.7-82.8)$ & $(3.7-83.8)$ \\
\hline \multirow{2}{*}{ Hemophilia B } & 15.3 & 15.6 & 16.4 & 17.4 & 18.5 \\
\hline & $(3.2-41.4)$ & $(2.2-42.5)$ & $(3.2-43.4)$ & $(4.2-44.4)$ & $(5.2-45.4)$ \\
\hline \multicolumn{6}{|c|}{ Clinically evident arthropathy } \\
\hline Total (\%) & $49(57.6)$ & $48(53.3)$ & $47(51.6)$ & $47(51.1)$ & $48(51.1)$ \\
\hline Severe (\%) & $31(79.4)$ & $32(76.2)$ & $31(75.6)$ & $31(75.6)$ & $32(78)$ \\
\hline Moderate (\%) & $18(64.2)$ & $16(55.1)$ & $16(55.2)$ & $16(56.3)$ & $16(51.6)$ \\
\hline Mild (\%) & 0 & 0 & 0 & 0 & 0 \\
\hline \multicolumn{6}{|c|}{ Presence of inhibitor } \\
\hline Hemophilia A & 2 & 2 & 2 & 1 & 1 \\
\hline Hemophilia B & 0 & 0 & 0 & 0 & 0 \\
\hline \multicolumn{6}{|l|}{ Positive serologies } \\
\hline Anti-HIV (\%) & $6(7.1)$ & $6(6.7)$ & $5(5.5)$ & $5(5.4)$ & $5(5.3)$ \\
\hline Anti-HCV (\%) & $29(34.1)$ & $29(32.2)$ & $28(30.8)$ & $28(30.4)$ & 29 (30.9) \\
\hline
\end{tabular}

(exodontia, tongue suture, bronchoscopy, prostate biopsy, facectomy, drainage of sebaceous cyst, canthoplasty, lymph node biopsy, and blepharoplasty).

In the period evaluated, three deaths occurred: one due to hemorrhagic stroke in a patient with AIDS, one due to an externally-caused hemorrhage, and one due to HCV associated with hepatic carcinoma.

With the implementation of prophylaxis in 2011 and the gradual inclusion of patients in this treatment regimen, there was an increase of $124.7 \%$ in the consumption of factor VIII 
Table 2. Multidisciplinary care for patients with hemophilia at the Regional Blood Center of Juiz de Fora, in the state of Minas Gerais, Brazil, 2011-2015

\begin{tabular}{|c|c|c|c|c|c|}
\hline & 2011 & 2012 & 2013 & 2014 & 2015 \\
\hline Patients & 85 & 90 & 91 & 92 & 94 \\
\hline \multicolumn{6}{|l|}{ Hematology - HRJF } \\
\hline Consultations (mean) & $\begin{array}{l}1,231 \\
(14.4)\end{array}$ & $\begin{array}{l}1,036 \\
(11.5)\end{array}$ & $963(10.6)$ & $967(10.5)$ & $973(10.3)$ \\
\hline Range & $0-90$ & $0-86$ & $0-95$ & $0-68$ & $0-78$ \\
\hline \multicolumn{6}{|l|}{ Emergency Services } \\
\hline Consultations (mean) & $50(0.59)$ & $27(0.3)$ & $22(0.24)$ & $42(0.46)$ & $37(0.39)$ \\
\hline Range & $0-30$ & $0-9$ & $0-3$ & $0-9$ & $0-11$ \\
\hline \multicolumn{6}{|c|}{ Nursing, Psychology, Dentistry, and Social Services } \\
\hline Appointments (mean) & $87(1.02)$ & $78(0.87)$ & $91(1)$ & $151(1.64)$ & $100(1.06)$ \\
\hline \multicolumn{6}{|c|}{ Administration of medications at the HRJF by nursing technicians } \\
\hline Infusion (mean) & $\begin{array}{c}1,249 \\
(14.69)\end{array}$ & $\begin{array}{c}1,016 \\
(11.29)\end{array}$ & $\begin{array}{c}956 \\
(10.51)\end{array}$ & $\begin{array}{c}925 \\
(10.05)\end{array}$ & $783(8.33)$ \\
\hline Range & $0-92$ & $0-88$ & $0-98$ & $0-82$ & $0-91$ \\
\hline \multicolumn{6}{|c|}{ Patients trained for home infusion } \\
\hline Home infusion (\%) & $33(38.8)$ & $33(36.7)$ & $40(44)$ & $46(50)$ & $50(53.2)$ \\
\hline \multicolumn{6}{|c|}{ Patients placed on prophylaxis } \\
\hline Total (\%) & 0 & 0 & $12(13.2)$ & $32(34.8)$ & $36(38.3)$ \\
\hline Primary & 0 & 0 & 1 & 2 & 3 \\
\hline Secondary & 0 & 0 & 1 & 4 & 4 \\
\hline Tertiary & 0 & 0 & 10 & 26 & 29 \\
\hline \multicolumn{6}{|c|}{ Patients using recombinant factor } \\
\hline Hemophilia A (\%) & 0 & 0 & $14(19.7)$ & $29(40.2)$ & $33(45.2)$ \\
\hline Hemophilia B (\%) & 0 & 0 & 0 & 0 & 0 \\
\hline
\end{tabular}

concentrate, ranging from 2,241,800 International Units (IU) in 2011 to 5,036,500 IU in 2015, with gradual replacement of plasma derived factor by recombinant factor. Regarding the treatment of hemophilia B, the increase in the consumption of factor IX concentrate was $94.4 \%$ in the same period (from $675,100 \mathrm{IU}$ to $1,312,750 \mathrm{IU}$ ).

The financial costs attributed to the treatment of hemophilia at the HRJF are specified in Table 3. The costs related to CFCs amounted to $99.46 \%$ of all expenses.

The estimated direct medical costs of hemophilia treatment at the HRJF increased by 286.8\% between 2011 and 2015, that is, ranging from $R \$ 35,403.30$ to $R \$ 101,547.18$ (Brazilian Reais) per patient, which corresponded to 3.46 times the Gross Domestic Product (GDP) per capita ${ }^{21}$. There was no significant difference between the mean annual direct medical costs for hemophilia $A$ or $B$ in the period analyzed $(R \$ 60,264.19$ versus $R \$ 47,578.75$ per patient and per year, $p=0.407)$. However, costs were higher when comparing severe to moderate hemophilia (respectively $R \$ 89,467.77$ and $R \$ 53,486.50$ per patient and per year, $p=0.013$ ), and moderate to mild $(R \$ 53,486.50$ versus $R \$ 2,962.10$ per patient and per year, $p<0.001)$ respectively. The mean 
Table 3. Mean direct medical costs, in Brazilian Reais* (R\$), of treatment per patient with hemophilia at the Regional Blood Center of Juiz de Fora, in the state of Minas Gerais, Brazil, 2011-2015

\begin{tabular}{lccccc} 
& $\mathbf{2 0 1 1}$ & $\mathbf{2 0 1 2}$ & $\mathbf{2 0 1 3}$ & $\mathbf{2 0 1 4}$ & $\mathbf{2 0 1 5}$ \\
\hline Patients & 85 & 90 & 91 & 92 & 94 \\
\hline Consultations & 237.08 & 184.72 & 171.41 & 174.66 & 159.44 \\
\hline Exams & 102.81 & 94.79 & 84.61 & 98.20 & 118.67 \\
\hline Procedures / hospitalizations & 32.62 & 17.68 & 36.98 & 42.00 & 121.71 \\
\hline Medications & $35,030.80$ & $37,175.14$ & $52,322.67$ & $80,324.28$ & $101,147.36$ \\
\hline Total & $35,403.30$ & $37,472.33$ & $52,615.67$ & $80,639.16$ & $101,547.18$ \\
\hline
\end{tabular}

* 1 American Dollar $=3.90$ Brazilian Reais (December 31, 2015)

annual cost of the patient with an inhibitor, treated with an ITI, was $R \$ 170,706.48$, that is, almost three times the total mean of $\mathrm{R} \$ 57,416.43$.

Since the cost analysis was done with an open population, paired sample t-tests were used to evaluate the evolution of the costs associated with treatment of the same individuals at different points in the study. Table 4 compares the year-over-year growth rate of costs associated with blood products of paired individuals, and Table 5 shows the mean annual costs by hemophilia type and severity. There was no statistically significant difference in mean annual costs between mild hemophilia cases, as well as between moderate hemophilia $A$ cases, perhaps because the latter was the most clinically heterogeneous group in this study.

Table 4. Year-over-year evolution rate of the mean costs related to Clotting Factor Concentrates (CFCs) for the treatment of patients with hemophilia at the Regional Blood Center of Juiz de Fora, in the state of Minas Gerais, Brazil, 2011-2015

\begin{tabular}{cccc}
$\begin{array}{c}\text { Comparison } \\
\text { period }\end{array}$ & $\begin{array}{c}\text { Individuals } \\
\text { evaluated }\end{array}$ & $\begin{array}{c}\text { Mean annual costs per patient, in } \\
\text { Brazilian Reais (R\$) }\end{array}$ & $\begin{array}{c}\text { Statistical } \\
\text { significance } \\
\text { (Wilcoxon) }\end{array}$ \\
\hline 2011 and 2012 & 85 & $34,838.74$ versus 39,339.01 & $\mathrm{p}=0.004$ \\
\hline 2012 and 2013 & 88 & $37,450.33$ versus 54,060.50 & $\mathrm{p}<0.001$ \\
\hline 2013 and 2014 & 91 & $52,322.35$ versus 80,129.43 & $\mathrm{p}<0.001$ \\
\hline 2014 and 2015 & 91 & $80,826.60$ versus 102,666.99 & $\mathrm{p}=0.002$ \\
\hline 2011 and 2015 & 82 & $34,997.59$ versus 109,177.84 & $\mathrm{p}<0.001$ \\
\hline
\end{tabular}

Table 5. Comparison of the mean costs, in Brazilian Reais, of Clotting Factor Concentrates (CFCs) used by patients from the Regional Blood Center of Juiz de Fora, by type and severity of hemophilia, in paired samples tests, in the city of Juiz de Fora, in the state of Minas Gerais, Brazil, 2011-2015

\begin{tabular}{cccc}
$\begin{array}{c}\text { Hemophilia type and } \\
\text { severity }\end{array}$ & $\begin{array}{c}\text { Individuals } \\
\text { evaluated }\end{array}$ & $\begin{array}{c}\text { Range of mean annual costs } \\
\text { from 2011 to 2015, in Brazilian } \\
\text { Reais (R\$) }\end{array}$ & $\begin{array}{c}\text { Statistical } \\
\text { significance } \\
\text { (Friedman) }\end{array}$ \\
\hline Hemophilia A - severe & 29 & $45,933.21$ to $183,779.82$ & $\mathrm{p}<0.001$ \\
\hline Hemophilia A - moderate & 19 & $44,295.13$ to $111,313.84$ & $\mathrm{p}=0.362$ \\
\hline Hemophilia A - mild & 14 & $1,877.46$ to $5,693.16$ & $\mathrm{p}=0.285$ \\
\hline Hemophilia B - severe & 9 & $49,566.90$ to $119,515.67$ & $\mathrm{p}=0.001$ \\
\hline Hemophilia B - moderate & 8 & $25,096.96$ to $42,345.22$ & $\mathrm{p}=0.003$ \\
\hline Hemophilia B - mild & 3 & $7,656.63$ to 4,632.64 & $\mathrm{p}=0.406$ \\
\hline Total & 82 & $34,997.59$ to $109,177.84$ & $\mathrm{p}<0.001$ \\
\hline
\end{tabular}


The real incremental impact costs after the incorporation of technologies in the treatment of hemophilia of HRJF patients was R\$6,172,925.89, when comparing with the year 2015 and 2012 (regarding the year prior to the use of the new technologies), that is, $R \$ 70,182.63$ per patient.

\section{DISCUSSION}

The treatment of hemophilia is extremely expensive and needs to be maintained throughout life ${ }^{10}$. Direct medical costs surpass those for the treatment of other chronic joint conditions, such as rheumatoid arthritis ${ }^{22}$.

The implementation of prophylaxis in Brazil was undeniably one of the major advances in the management of patients with hemophilia, especially of children, in whom arthropathy can be avoided or delayed by adequate replacement of factor concentrates ${ }^{1}$. While in adults, treatment is focused solely on factor replacement, seeing that the orthopedic approach and rehabilitation remain in the background.

The reduction of $21 \%$ in the number of consultations and $37.3 \%$ in infusions between 2011 and 2015 was due to the institution of prophylaxis and the constant training of the patients and/or caregivers for home administration of factor concentrates. Patients placed on prophylaxis had a reduced frequency of bleeding events and need few medical cares. Moreover, patients trained for home infusion made fewer visits to the blood center for infusions ${ }^{1}$.

The greater increase in factor VIII consumption could be explained by the greater number of individuals with hemophilia A who adhered to prophylaxis (32) compared to those with hemophilia $B(7)$, and the prophylaxis protocols used that indicate more weekly infusions of factor for hemophilia A than for $B^{2}$.

There was no increase in direct medical costs following the incorporation of new technologies (prophylaxis, recombinant factor VIII, and immune tolerance) in the treatment of patients with mild hemophilia, principally because they do not benefit from prophylaxis or ITI, since they do not usually present spontaneous bleeding requiring prevention and rarely develop inhibitors ${ }^{23}$. Although they may have used recombinant factor VIII, consumption was occasional and generally very low.

Among the individuals evaluated in this study, arthropathy was present in the great majority of patients with severe hemophilia, and in approximately half of those with moderate hemophilia. Even so, no imaging exam was requested for staging arthropathy and no orthopedic surgery was performed, which could be more cost-effective than tertiary prophylaxis in subsets of patients with incapacitating arthropathy ${ }^{6,24}$. Synoviorthesis for the treatment of target joints still had not been incorporated by the SUS, and it could be noted that follow-up of physical therapy was also rejected, revealing the fragmentation of care for patients with hemophilia.

With the adoption of prophylaxis without prior staging of joint lesions, no further costeffectiveness analysis of such an expensive treatment will be possible ${ }^{25}$. Since the patient's basal joint arthritis has not been evaluated, there will be no parameters for the benefits of the prophylaxis to be recognized in this patient.

Considering that the cost of a single dose of recombinant factor VIII for a $70 \mathrm{~kg}$ adult would be sufficient to finance, according to the perspective of the SUS, it could be noted 247 consultations with orthopedists, 530 physiotherapy sessions, simple knee, elbow, and ankle x-rays of 64 patients, 102 joint ultrasounds or even nine MRIs in 2015 ${ }^{15,16}$, however, it is evident the lack of coordination of the proposed treatment and not just the scarcity of financial resources.

All AIDS patients at the HRJF could receive regular treatment with antiretroviral therapy, which was not included in the cost analysis. Although for contextual purposes, according to the price table of the ANVISA in December 2015, the cost of antiretroviral drugs recommended at the time, as the first choice, would be $R \$ 1,707.35$ per month. In the same table, the price of $1,000 \mathrm{IU}$ of recombinant factor VIII concentrate was $\mathrm{R} \$ 2,033.13$, noting that a prophylactic dose of factor VIII for a $70 \mathrm{~kg}$ man is 1,500-2,000 IU ${ }^{15}$ and three doses are used per week'. 
Hospitalizations, known to be more expensive for patients with hemophilia, were rare, and all those related to hemorrhagic complications occurred with patients in episodic treatment ${ }^{26}$. The deaths recorded in the period confirmed that mortality is still due to bleeding or complications of diseases transmissible through blood, acquired mainly in the $1980 \mathrm{~s}^{27}$.

Similar to the published international economic analyses, CFCs accounted for more than $99 \%$ of the direct medical costs of treatment. However, it is worth noting that, while the price of CFCs varies according to the international market, since all the required supply is still imported, payments for services and procedures by the SUS are very low and lagging when compared to practices in developed countries ${ }^{16,28}$.

One limitation of this study was the use of the prices of CFCs contained in the ANVISA tables. Although this information comes from an official entity, they may not correspond to the amounts actually paid by the Federal Government in the electronic exchanges. The tables were used since the prices applicable in this bidding modality, between 2011 and 2015, were not available for consultation.

Unfortunately, because of the joint implementations of prophylaxis, ITI, and the use of recombinant factor VIII concentrate, effectively taking place in 2013, it was not possible to calculate the actual impact costs of each technology separately.

According to Anderson, retrospective and empirical studies tend to produce more generalizable results in health cost analyses ${ }^{29}$. However, the heterogeneity of resources available for the care of persons with hemophilia in the various treatment centers in Brazil is an important obstacle to this inference. The incremental real impact costs on the HRJF of more than six million Reais, being considered throughout Brazil, would correspond to approximately 690 million Reais in 2015. Concerning this amount, the direct medical costs of the SUS in that year, for medical consultations and clinical and surgical hospitalizations, due to cardiovascular diseases, which are much more prevalent than hemophilia, consisted of only seven times that value ${ }^{30}$.

Seeing that this is a retrospective study, it was not possible to include the indirect costs of hemophilia. Although it was not one of the research objectives, knowledge of indirect costs, even by estimating it, could reflect even more intensely the immense financial burden imposed by this disease.

The results could suggest that CFCs accounted for the great majority of costs in hemophilia. The direct medical costs of the treatment of hemophilia increase were very high in the HRJF with the incorporation of new technologies, although there are some areas with inefficiencies in the management of patients with this coagulopathy. The absence of other partial economic analyses on hemophilia conducted in Brazil makes it impossible to compare the results, but the actual data generated here can be used to calibrate criteria adopted in future studies and to assist managers regarding investment priorities.

\section{REFERENCES}

1. Srivastava A, Brewer AK, Mauser-Bunschoten EP, Key NS, Kitchen S, Llinas A, et al. Guidelines for the management of hemophilia. Haemophilia. 2013 jan;19(1):e1-47. http://dx.doi.org/10.1111/j.13652516.2012.02909.x. PMid:22776238.

2. Brasil. Ministério da Saúde. Secretaria de Atenção à Saúde. Departamento de Atenção Especializada e Temática. Manual de hemofilia. 2. ed. Brasília: Ministério da Saúde, 2015. 80 p.

3. Blanchette VS, Key NS, Ljung LR, Manco-Johnson MJ, van den Berg HM, Srivastava A, et al. Definitions in hemophilia: communication from the SSC of the ISTH. JThromb Haemost. 2014 nov;12(11):1935-9. http:// dx.doi.org/10.1111/jth.12672. PMid:25059285.

4. Makris M. Prophylaxis in haemophilia should be life-long. Blood Transfus. 2012;10(2):165-8. http://dx.doi. org/10.2450/2012.0147-11. PMid:22337280.

5. Oldenburg J. Optimal treatment strategies for hemophilia: achievements and limitations of current prophylactic regimens. Blood. 2015 mar;125(13):2038-44. http://dx.doi.org/10.1182/ blood-2015-01-528414. PMid:25712992.

6. Schramm W, Berger K. Economics of prophylactic treatment. Haemophilia. 2003 may;9(Suppl 1):111-5; dicussion 116. http://dx.doi.org/10.1046/j.1365-2516.9.s1.14.x. 
7. Ullman $M$, Hoots WK. Assessing the costs for clinical care of patients with high responding factor VIII and IX inhibitors. Haemophilia. 2006 dec;12(Suppl 6):74-9, discussion 79-80. http://dx.doi.org/10.1111/j.13652516.2006.01370.x. PMid:17123398.

8. Fitch KV, Pyenson BS. Benefit designs for high cost medical conditions. New York: Milliman Inc; 2011.

9. Guh S, Grosse SD, McAlister S, Kessler CM, Soucie JM. Health care expenditures for males with haemophilia and employer-sponsored insurance in the United States, 2008. Haemophilia. 2012;18(2):268-75. http:// dx.doi.org/10.1111/j.1365-2516.2011.02692.x. PMid:22151000.

10. Chen SL. Economic costs of hemophilia and the impact of prophylactic treatment on patient management. Am J Manag Care. 2016 apr;22(5 Suppl):s126-33. PMid:27266809.

11. Johnson KA, Zhou ZY. Costs of care in hemophilia and possible implications of health care reform. Hematology (Am Soc Hematol Educ Program). 2011;2011(1):413-8. http://dx.doi.org/10.1182/ asheducation-2011.1.413. PMid:22160067.

12. Brasil. Ministério da Saúde. SUS garante tratamento preventivo para hemofílicos [Internet]. Brasília: Ministério da Saúde; 2011 [cited 2016 Feb 20]. Available from: http://portalsaude.saude.gov.br/index. $\mathrm{php/cidadao/principal/agenciasaude/noticias-anteriores-agencia-saude/1229-sus-garante-tratamento-}$ brpreventivo-para-hemofilicos

13. Brasil. Ministério da Saúde. MS recomenda tratamento preventivo da hemofilia [Internet]. Brasília: Ministério da Saúde; 2012 [cited 2016 Feb 20]. Available from: http://portalsaude.saude.gov.br/ index.php/cidadao/principal/agenciasaude/noticias-anteriores-agencia-saude/2592-ms-recomendatratamentopreventivo-da-hemofilia

14. Brasil. Ministério da Saúde. Portaria n 478, de 16 de junho de 2014. Aprova o Protocolo de Uso de Indução de Imunotolerância em Pacientes com Hemofilia A e Inibidor. Diário Oficial da União [Internet] Brasília, 2014. [cited 2016 Oct 21]. Available from: http://bvsms.saude.gov.br/bvs/saudelegis/sas/2014/ prt0478_16_06_2014.html

15. Brasil. Ministério da Saúde. SIGTAP-Sistema de Gerenciamento da Tabela de Procedimentos, Medicamentos e OPM do SUS [Internet]. Brasília: Ministério da Saúde; 2018 [cited 2018 Mar 21]. Available from: http:// sigtap.datasus.gov.br/tabela-unificada/app/sec/inicio.jsp

16. Brasil. Agência Nacional de Vigilância Sanitária. Listas de preços de medicamentos - anos anteriores [Internet]. Brasília: Ministério da Saúde; 2018 [cited 2018 Mar 21]. Available from: http://portal.anvisa. gov.br/anos-anteriores

17. Marshall DA, Douglas PR, Drummond MF, Torrance GW, Macleod S, Manti O, et al. Guidelines for conducting pharmaceutical budget impact analyses for submission to public drug plans in Canada. Pharmacoeconomics. 2008;26(6):477-95. http://dx.doi.org/10.2165/00019053-200826060-00003. PMid:18489199.

18. Poonnoose PM, van der Net J. Musculoskeletal outcome in hemophilia: bleeds, joint structure and function, activity, and health-related fitness. Semin Thromb Hemost. 2015 nov;41(8):872-9. http://dx.doi. org/10.1055/s-0034-1543997. PMid:25923063.

19. Simpson ML, Valentino LA. Deficiency and osteoporosis in hemophilia: an underappreciated risk. Blood. 2013;122(21):3593. http://dx.doi.org/10.1182/blood.V122.21.3593.3593.

20. AlbayrakC, AlbayrakD.Vitamin D levels in children with severe hemophilia A: an underappreciated deficiency. Blood Coagul Fibrinolysis. 2015 apr;26(3):285-9. http://dx.doi.org/10.1097/MBC.0000000000000237. PMid:25485786.

21. Instituto Brasileiro de Geografia e Estatística. Brasil em Síntese. Contas nacionais: PIB per capita [Internet]. Rio de Janeiro: IBGE; 2017 [cited 2017 July 17]. Available from: http://brasilemsintese.ibge.gov.br/contasnacionais/pib-percapita.html

22. Buendgens FB, Blatt CR, Marasciulo ACE, Leite SN, Farias MR. Estudo de custo-análise do tratamento da artrite reumatoide grave em um município do Sul do Brasil. Cad Saude Publica. 2013;29(Supl 1):s81-91. http://dx.doi.org/10.1590/0102-311X00013513.

23. Witmer C, Young G. Factor VIII inhibitors in hemophilia A: rationale and latest evidence. Ther Adv Hematol. 2013;4(1):59-72. http://dx.doi.org/10.1177/2040620712464509. PMid:23610614.

24. Shrestha A, Eldar-Lissai A, Hou N, Lakdawalla DN, Batt K. Real-world resource use and costs of haemophilia A-related bleeding. Haemophilia. 2017 july;23(4):e267-75. http://dx.doi.org/10.1111/hae.13220. PMid:28574162.

25. Knobe K, Berntorp E. Haemophilia and joint disease: pathophysiology, evaluation, and management. Journal of Comorbidity. 2011;1(1):51-9. http://dx.doi.org/10.15256/joc.2011.1.2. PMid:29090136. 
26. Fredericks M, Pyenson B, Iwasaki K. An actuarial study of hemophilia: implications for commercial and Medicaid managed care plans [Internet]. New York: Milliman, Inc; 2014 [cited 2017 Feb 17]. Available from: https://www.milliman.com/en/insight/an-actuarial-study-of-hemophilia-implications-for-commercialand-medicaid-managed-care-pl

27. Darby SC, Kan SW, Spooner RJ, Giangrande PL, Hill FG, Hay CR, et al. Mortality rates, life expectancy, and causes of death in people with hemophilia A or B in the United Kingdom who were not infected with HIV. Blood. 2007 aug;1 10(3):815-25. http://dx.doi.org/10.1182/blood-2006-10-050435. PMid:17446349.

28. O'Hara J, Hughes D, Camp C, Burke T, Carroll L, Diego DG. The cost of severe haemophilia in Europe: the CHESS study. Orphanet J Rare Dis. 2017 may;12(1):106. http://dx.doi.org/10.1186/s13023-017-0660-y. PMid:28569181.

29. Anderson R. Systematic reviews of economic evaluations: utility or futility? Health Econ. 2010;19(3):35064. http://dx.doi.org/10.1002/hec.1486. PMid:19378354.

30. Siqueira ASE, Siqueira-Filho AG, Land MGP. Análise do impacto econômico das doenças cardiovasculares nos últimos cinco anos no Brasil. Arq Bras Cardiol. 2017 july;109(1):39-46. http://dx.doi.org/10.5935/ abc.20170068. PMid:28591251. 